Food Webs

September 2019, Volume 20 Pages e00121 (9p.)

https://doi.org/10.1016/i.fooweb.2019.e00121

https://archimer.ifremer.fr/doc/00512/62335/

\title{
Eutrophication disrupts summer trophic links in an estuarine microbial food web
}

\author{
López-Abbate M.C. ${ }^{1,}{ }^{*}$, Molinero Juan-Carlos ${ }^{2}$, Barría De Cao M.S. ${ }^{1}$, Silva R. ${ }^{3}$, Negri R. ${ }^{3}$,
} Guinder V.A. ${ }^{1}$, Hozbor M.C. ${ }^{3}$, Hoffmeyer M.S. ${ }^{1}$

\author{
${ }^{1}$ Instituto Argentino de Oceanografía (CONICET-UNS), Camino La Carrindanga km 7.5, 8000 Bahía \\ Blanca, Argentina \\ 2 Institut de Recherche pour le Développement (IRD), UMR248 MARBEC, IRD/CNRS/IFREMER/UM, \\ Sète Cedex, France \\ 3 Instituto Nacional de Investigación y Desarrollo Pesquero (INIDEP), Paseo Victoria Ocampo №1, \\ B7602HSA Mar del Plata, Buenos Aires, Argentina
}

* Corresponding author : M. C. López-Abbate, email address : mclabbate@iado-conicet.gob.ar

\begin{abstract}
:
Eutrophication is the most widespread effect of urban development in coastal areas. To elucidate how nutrient loading affects the carbon pathways at the base of food chains, we quantified the carbon transfer among microbial components, from prokaryotes to microzooplankton. For this purpose, we performed two size-fractionation feeding experiments during late summer under moderate $(\mathrm{N}: 28.5 \mu \mathrm{M}, \mathrm{P}: 0.92 \mu \mathrm{M}$, Si: $45.8 \mu \mathrm{M})$ and severe $(\mathrm{N}: 173.9 \mu \mathrm{M}, \mathrm{P}: 3.5 \mu \mathrm{M}$, Si: $67.2 \mu \mathrm{M})$ cultural eutrophication in the Bahía Blanca Estuary (Argentina). In both experiments, prokaryotes were largely dominated by heterotrophic forms, small diatoms dominated among autotrophs, and heterotrophic nanoflagellates were the most abundant among protistan grazers. Under severe eutrophication, however, the average biomass was $75 \%$ lower for all autotrophic and heterotrophic components. Nutrient loading sustained a higher growth rate of heterotrophic bacteria and phytoplankton but implied poorer trophic transfer. Under moderate eutrophication, daily productivity of nanoplankton and bacteria grazed was $157 \%$ and $154 \%$, respectively, while under severe eutrophication, this percentage dropped to $3.54 \%$ and $33.7 \%$, respectively. In addition, under excess nutrient conditions, microzooplankton evidenced an active prey switching toward the most abundant prey (diatoms). Weak top-down control of bacterial biomass along with trophic decoupling between microzooplankton and nanoflagellates, constituted a dead-end of bacterial biomass under severe cultural eutrophication. This inefficient carbon transfer can potentially produce a positive feedback by exacerbating organic matter accumulation.
\end{abstract}

Keywords : Eutrophication, Microbial food web, Bacteria, Nanoflagellates, Microzooplankton, Estuaries 


\section{Introduction}

The ocean-land interface act as a buffer of human disturbance, but is also highly vulnerable to human activities and urban settlements (Glavovic et al. 2015). Draining of urban effluents and the subsequent shift of nutrient balance are among the most widespread effect of human activities in coastal areas. Immediate ecological responses to such changes promote the reconfiguration of autotrophic communities and the increased frequency, intensity and duration of algal blooms (Paerl et al. 2014). For instance, in eutrophic systems such as estuaries, variations in the N:P ratio due to allochthonous pulses of nutrients, change the size spectrum of primary producers by stimulating the growth of smaller organisms with higher nutrient affinities (McCarthy et al. 2007, Domingues et al. 2011, Suikkanen et al. 2013). Moreover, nutrient loading is often linked with the limitation of diatom growth due to silicate deficiency and the proliferation of non-siliceous, unpalatable algae (Officer and Ryther 1980, Breton et al. 2006, Panizzo et al. 2018). Alternatively, primary producers and heterotrophic bacteria may utilize inorganic nutrients outside the Redfield ratio thus altering their intracellular C:N:P ratio (Mills and Arrigo 2010, Meunier et al. 2014, Trautwein et al. 2017). Modifications on prey stoichiometry, in turn, reduce the performance of phagotrophs due to nutritional deficiencies (Malzahn et al. 2010). Phagotrofic protists, however, are able to thrive among preys with different intracellular composition and palatability (Ger et al. 2014). In eutrophic systems such as estuaries, microzooplankton is able to graze an average of 60 $\%$ of daily primary production (Schmoker et al. 2013). Less attention has been paid on the grazing impact of heterotrophic nanoflagellates (HNF) in eutrophic areas. Observations revealed that grazing by HNF is highly dependent on temperature and constitute a primary mortality factor of bacteria during the warm season (Bong and Lee 2011, Ortmann et al. 2011, Tsai et al. 2013). 
While there is some consensus on the effect of eutrophication on the structure of microbial food webs, little is known about how nutrient loading affects the carbon pathways among microbes (Schmoker et al. 2016, Özen et al. 2017). This uncertainty is partly related with the lack of detailed studies that incorporate a food web approach (D'Alelio et al. 2016). This is a critical issue given that eutrophication can reduce the efficiency of food webs, in part as a result of the decrease in the grazer-to-prey ratio and the limited capacity of grazers to control algal proliferations (Calbet et al. 2014). Former studies using a food web approach in the Bahia Blanca Estuary have shown a discontinuous trophic interaction between microzooplankton and phytoplankton; in particular, a low microzooplankton potential to control phytoplankton blooms when exposed to severe eutrophication (López-Abbate et al. 2016). To date, however, the role of bacteria and nanoflagellates remains uncertain.

Here we conducted two feeding experiments to quantify carbon pathways among the microbial food web, from bacteria to microzooplankton, during late summer in the Bahía Blanca Estuary (Argentina). The estuary is a flood-plain ecosystem exposed to diverse anthropogenic activities and to point-source untreated domestic effluent (Marcovecchio et al., 2008). Our aim was to identify the main pathways of carbon transfer under contrasting exposure to human-driven eutrophication. To quantify the grazing impact of HNF and microzooplankton over size-specific prey, we employed the size-fractionation method that allows a detailed examination of trophic links.

\section{Materials and Methods}

\section{Experimental set-up and rate calculation}

Feeding experiments were performed at two sites within the Bahía Blanca Estuary $\left(38^{\circ} 45^{\prime}-\right.$ $\left.39^{\circ} 40^{\prime} \mathrm{S}, 61^{\circ} 45^{\prime}-62^{\circ} 30^{\prime} \mathrm{W}\right)$, which is located in the southwestern Atlantic Ocean coast, 
Argentina. The sampling sites were selected by considering similar geomorphological features, but contrasting exposure to sewage input (Fig. 1). Both sites are located within tidal channels ranging 50-300 $\mathrm{m}$ width and 4-7 $\mathrm{m}$ depth. The first experiment was performed at Bahía del Medio (BM), which is not directly impacted by human stress (Baldini et al. 1999, Hoffmeyer and Barría de Cao 2007), while the second experiment was conducted in Canal Vieja (CV), a site directly affected by cultural eutrophication since it receives point-source untreated domestic effluent from the adjacent Bahía Blanca city (300,000 inhab.). The experiments were daily-deployed on March 6, 2012, to match the seasonal pulse of microzooplankton (Barría de Cao et al. 2011) and the first annual phytoplankton bloom (Guinder et al. 2013).

The size fractionation method was used to compute the growth and grazing rates by comparing prey biomass at the beginning and end of an incubation period in the presence and absence of predators (Sato et al. 2007, Vargas et al. 2008, Paulsen et al. 2016). For this purpose, three size fractions were established: 0.2-3 $\mu \mathrm{m}$ (bacteria and cyanobacteria), 2-20 $\mu \mathrm{m}$ (diatoms and other phytoplankton, phototrophic $[\mathrm{PNF}]$ and heterotrophic nanoflagellates $[\mathrm{HNF}]$ ) and 20-135 $\mu \mathrm{m}$ (microphytoplankton and microzooplankton). The aim of this procedure is to eliminate size-specific grazers. The first two size fractions, $0.2-3 \mu \mathrm{m}$ and 2$20 \mu \mathrm{m}$, were obtained by screening surface seawater through 3 and $20 \mu \mathrm{m}$ pore size filters, respectively, employing low vacuum $(<10 \mathrm{mmHg})$. The third fraction, 20-135 $\mu \mathrm{m}$, was obtained by reverse filtration through a $135 \mu \mathrm{m}$ pore size mesh. The handling of water samples was carried out at room temperature within an indoor facility located at the riverine area, close to the sampling stations, and with extreme care to minimize the damage of organisms. From each size fraction, triplicate samples were reserved to register the initial composition, concentration and biomass of preys and grazers. Subsequently, three aliquots 
(0.5 1) from each size fraction were placed on acid-cleaned polycarbonate bottles by reverse filtration and taken to the incubation site (Fig. 2). All incubation bottles were tightly capped after filling, thus avoiding air bubbles. Incubations were performed at the exact site of water collection to maintain in situ temperature and photoperiod. Bottles were placed within bags of woven nylon threads with a $5 \mathrm{~cm}$ mesh size that allowed the passage of light. After completing these procedures, bags were immediately placed near the surface $(0.5 \mathrm{~m}$ depth $)$ and fixed to the bottom by an anchor (Fig 2). At the end of the incubation period (24 h), samples were taken from each bottle to register the final composition, concentration and biomass of preys and grazers.

Grazing by HNF and microzooplankton was computed by measuring cell removal during the incubation period. For this purpose, we compared cell abundance and biomass at the beginning and end of the incubation period in each bottle. The $0.2-3 \mu \mathrm{m}$ and $2-20 \mu \mathrm{m}$ size fractions were confronted to assess HNF grazing on bacteria and cyanobacteria, while the 2$20 \mu \mathrm{m}$ and $20-135 \mu \mathrm{m}$ size fractions were confronted to compute microzooplankton grazing on PNF, HNF, diatoms and other phytoplankton (Frost 1972, Gifford 1993). The following equations were used to calculate prey growth, $\mu\left(\mathrm{d}^{-1}\right)$, and mortality rates, $m\left(\mathrm{~d}^{-1}\right)$ :

$$
\begin{gathered}
\mathrm{P}_{2}=\mathrm{P}_{1} \mathrm{e}^{\mu\left(\mathrm{t}_{2}-\mathrm{t}_{1}\right)} \\
\mathrm{P}_{2}^{*}=\mathrm{P}_{1} \mathrm{e}^{(\mu-m)\left(\mathrm{t}_{2}-\mathrm{t}_{1}\right)}
\end{gathered}
$$

where $\mathrm{P}_{1}$ and $\mathrm{P}_{2}$ are the prey concentration at the beginning $\left(\mathrm{t}_{1}\right)$ and end $\left(\mathrm{t}_{2}\right)$ of the incubation period and $\mathrm{P}_{2} *$ is the concentration of prey at the end of the incubation bottle within bottles with grazers. The filtration rate, $\mathrm{F}\left(\mu 1 \operatorname{grazer}^{-1} \mathrm{~h}^{-1}\right)$, was calculated as follows:

$$
F=\frac{V m}{N}
$$


were $\mathrm{V}$ is the volume of the incubation bottle and $\mathrm{N}$ is the number of grazers in the bottle. The proportion of bacterial production consumed by HNF and primary production consumed by microzooplankton, was estimated as the quotient between $m$ and $\mu$. The ratio was then transformed to their arctangent in order to reduce the effect of large values. Range and average percentage were converted back to percent production consumed using the tangent function (Calbet and Landry 2004).

\section{Field data}

Sea surface temperature (SST), salinity, turbidity, $\mathrm{pH}$, dissolved oxygen concentration and saturation were simultaneously measured using a digital multi-sensor Horiba U-10. In addition, the concentrations of ammonium $\left(\mathrm{NH}_{4}{ }^{+}\right)$, nitrate $\left(\mathrm{NO}_{2}{ }^{-}\right)$, nitrite $\left(\mathrm{NO}_{3}{ }^{-}\right)$, phosphate $\left(\mathrm{PO}_{4}{ }^{3+}\right)$ and silicate $(\mathrm{Si})$, were determined following the methods described in Spetter et al. (2015). Three measurements per parameter were performed.

\section{Plankton enumeration and identification}

Sub-samples from the initial and final treatments were taken for plankton quantification by light and epi-fluorescence microscopy. Samples for pico- and nanoplankton analysis (10 ml) were fixed with $0.53 \mathrm{ml}$ of formaldehyde (f.c. $2 \%$ ) and subsequently processed following the methods described by Porter and Feig (1980). Heterotrophic bacteria and cyanobacteria were quantified by staining $1 \mathrm{ml}$ seawater sample with 4,6-diamidino-2-phenylindole (DAPI) to a final concentration of $3 \mu \mathrm{g} \mathrm{ml}^{-1}$ and collected on black polycarbonate filters $(25 \mathrm{~mm}$ diameter, $0.2 \mu \mathrm{m}$ pore size). The enumeration was done with a microscope Nikon Eclipse 80i equipped with a fluorescence lamp at 100X magnification. Heterotrophic bacteria were identified using a UV excitation filter (330-385 nm) while cyanobacteria were identified 
using a green excitation filter $(480-550 \mathrm{~nm})$. Ten images were taken at random points from each polycarbonate filter using a Nikon DXM1200F digital camera and subsequently, every cell in the image was enumerated and sized using the software ImageJ. Bacteria cell volumes were calculated assigning simple geometric shapes to species (coccos, bacillus), and converted into carbon content $\left(\mu \mathrm{g} \mathrm{C} 1^{-1}\right)$ by the allometric model according to Simon and Azam (1989).

The identification of diatoms and other phytoplankton, PNF and HNF was done by a combination of light and epi-fluorescent microscopy. Prior to the enumeration of organisms, preserved samples $\left(5 \mathrm{ml}\right.$ ) were stained with DAPI (f.c. $5 \mu \mathrm{g} \mathrm{ml}^{-1}$ ) and proflavin (f.c. $5 \mu \mathrm{g} \mathrm{ml}^{-}$

${ }^{1}$ ) and collected on black polycarbonate filters ( $25 \mathrm{~mm}$ diameter, $0.2 \mu \mathrm{m}$ pore size) (Verity and Sieracki 1993). Most PNF and HNF were identified using a blue excitation filter (450$490 \mathrm{~nm}$ ) while Cryptophytes were identified using a green excitation filter (480-550 nm). The enumeration of organisms was done by settling the preserved sample $(1-2 \mathrm{ml})$ in Utermöhl chambers during $24 \mathrm{~h}$ (Hasle 1978). The entire chamber was analysed under a Wild M20 inverted light microscope. Similarly, the enumeration of phytoplankton and microzooplankton in the size fraction $>135 \mu \mathrm{m}$ was done by settling a variable volume (10$50 \mathrm{ml}$, depending on sediment and plankton concentration) of preserved seawater sample (Lugol's iodine) in Utermöhl chambers during $24 \mathrm{~h}$. Biomass was estimated by assigning simple geometric shapes to species to quantify cell volume which was then converted into carbon content $\left(\mu \mathrm{g} \mathrm{C} \mathrm{l}^{-1}\right)$ according to Hillebrand et al. (1999).

\section{Data analysis}

Differences of biotic and abiotic variables between sites were calculated by linear regression models and One-way ANOVA. All data were tested for normality prior to analysis. The 
structure of plankton, i.e. taxonomic composition, in both sites was compared by non-metric Multi-Dimensional Scaling (MDS) using the R-package vegan. The technique was based on triangular matrix using the Bray Curtis similarity index (Clarke and Warwick 1994). A biplot was used to visualize the correlation of external variables (species) on a MDS. Significant differences in the plankton structure between sites were calculated by a One-way Analysis of Similarities (ANOSIM) at a significance level of $\mathrm{p}<0.05$ and $\mathrm{R}$ statistic $>0.5$. Similarity Percentages Analysis (SIMPER) was used to assess the contribution of each species to the similarity within groups and dissimilarity between groups. Feeding selectivity of microzooplankton was estimated by computing the selectivity index (Vanderploeg and Scavia 1979).

\section{Results}

\section{Environmental conditions}

Environmental variables at the beginning of the feeding experiments are shown in Table 1. SST, salinity, dissolved oxygen concentration, \% oxygen saturation and $\mathrm{pH}$ were similar in both sites. The concentration of all inorganic nutrients was higher in $\mathrm{CV}(\mathrm{p}<0.05$, One-way ANOVA, Table 1), while water turbidity was higher in BM ( $\mathrm{p}=0.040$, One-way ANOVA). The ratio between nitrogen, silicate and phosphate (N:Si:P) at the beginning of the experiment was 27:29:1 in BM and 47:10:1 in CV.

\section{Microbial community structure}

The mean biomass of preys and grazers at the beginning of the feeding experiments is shown in Figure 3. The species composition of nanoplankton and microzooplankton was markedly different between both sites (Figure 4). Thalassiosira minima, HNF, PNF>5 $\mu \mathrm{m}$, Paralia 
sulcata and Thalassionema nitzschioides, contributed with $84 \%$ to the total dissimilarity between sites (ANOSIM $\mathrm{p}<0.05, \mathrm{R}=0.50$ ). The mean concentration of heterotrophic bacteria

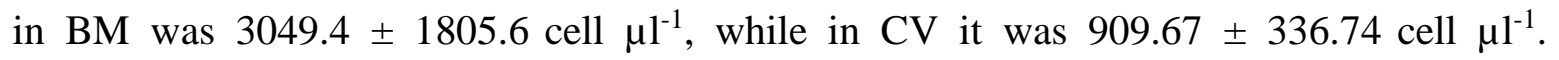
Cyanobacteria concentration was considerably lower and varied between $21.21 \pm 3.06$ cell $\mu \mathrm{l}^{-1}$ in $\mathrm{BM}$ and $1.29 \pm 2.24$ cell $\mu \mathrm{l}^{-1}$ in $\mathrm{CV}$. The abundance of total nanoplankton (phototrophic and heterotrophic plankton in the size range between 2 and $20 \mu \mathrm{m}$ ) was $300.13 \pm 24.75$ cell $\mu \mathrm{l}^{-1}$ in $\mathrm{BM}$ and $85.31 \pm 8.34$ cell $\mu \mathrm{l}^{-1}$ in $\mathrm{CV}$. Total nanoplankton biomass was dominated by diatoms, such as Thalassiosira minima, Cyclotella spp. and Thalassionema nitzchioides (Figure 5a). Diatoms constituted the 45 and $54 \%$ of the total nanoplankton biomass in BM and $\mathrm{CV}$, respectively. Among nanoflagellates, the most abundant groups were Pyramimonas sp., unidentified phototrophic flagellates in the size range higher than $5 \mu \mathrm{m}(\mathrm{PNF}>5 \mu \mathrm{m})$ and picoeukaryotes $(\mathrm{PNF}<5 \mu \mathrm{m})$. PNF constituted the 10 and $13 \%$ of the total nanoplankton biomass in $\mathrm{BM}$ and $\mathrm{CV}$ respectively, while $\mathrm{HNF}$ constituted 39 and $24 \%$ of total nanoplankton biomass in $\mathrm{BM}$ and $\mathrm{CV}$, respectively. Dinoflagellates and other groups such as coccolithophores, nanociliates, Calycomonas spp. and euglenophytes constituted less than $2 \%$ of total nanoplankton biomass (Figure 5a). Microzooplankton abundance ranged

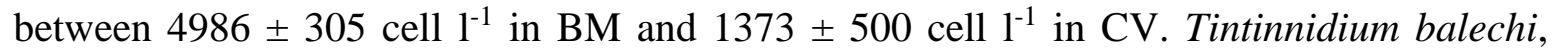
Tintinnopsis brasiliensis and T. levigata, were the most abundant species among ciliates, while nauplii constituted the most important item in terms of carbon biomass in CV (Figure $5 b)$.

Growth, grazing and feeding selectivity

The growth and productivity rate of plankton components are summarized in Figure 6. Diatoms showed a significantly higher growth and productivity rate in $\mathrm{CV}$, while $\mathrm{HNF}$ 
showed significantly higher values of productivity in this site (Table 2). Conversely, the grazing of HNF on bacteria, and the grazing and filtration rate of microzooplankton on HNF were significantly higher in BM (Figure 7, Table 2). This resulted on wide differences in the $\%$ of nanoplanktonic productivity (NP) grazed in the two sites; in BM microzooplankton consumed an average of $157 \%$ of NP, while in CV this percentage dropped to 3.54. The widest difference was found on the percentage of HNF productivity grazed per day that varied from $92.7 \%$ in $\mathrm{BM}$ to $0 \%$ in $\mathrm{CV}$. HNF consumed $154 \%$ of bacterial productivity in BM and $33.7 \%$ in CV (Figure 8).

During the feeding experiments, most prey items were either avoided $(\mathrm{Ei}<0)$ or ignored $(\mathrm{Ei}=0)$ (Figure $5 \mathrm{a})$. In $\mathrm{BM}$, the $61 \%$ of prey was negatively selected and the $11 \%$ was ignored, while in CV, the $69 \%$ were negatively selected and $15 \%$ ignored. Selected prey items by microzooplankton in BM were Paralia sulcata, Karenia mikimatoi, Prorocentrum micans, Protoperidinium aff. bipes, Calycomonas sp.2, nanociliates and coccolithophores. In $\mathrm{CV}$, the microzooplankton actively fed on Asterionellopsis glacialis, Cylindrotheca closterium, Skeletonema sp. and Calycomonas sp.2.

\section{Discussion}

Eutrophication effect on the structure of the microbial community

Wastewater effluents produced a significant increase on all inorganic nutrients, especially $\mathrm{NH}_{4}{ }^{+}$. Excess nutrients produced a negative effect on the biomass of all microbial components, including phytoplankton. A similar negative effect of cultural eutrophication on phytoplankton biomass and productivity was documented in other coastal habitats. Observational evidence indicates that the negative effect can be attributed to the inhibition of growth and $\mathrm{NO}_{3}^{-}$uptake by excess $\mathrm{NH}_{4}{ }^{+}$(Yoshiyama and Sharp 2006, Cox et al. 2009, 
Waiser et al. 2011, Dugdale et al. 2012, Parker et al. 2012, Glibert et al. 2014). Dugdale et al. (2007), conducted enclosure experiments in the San Francisco Bay and determined that $\mathrm{NH}_{4}{ }^{+}$concentration exceeding $4 \mu \mathrm{M}$ inhibits growth by preventing cells access to $\mathrm{NO}_{3}{ }^{-}$, although other authors have reported a threshold value close to $10 \mu \mathrm{M}$ in the Delaware Bay (Yoshiyama and Sharp 2006). $\mathrm{NH}_{4}{ }^{+}$concentration near the sewage outflow in the Bahía Blanca Estuary can eventually exceed $150 \mu \mathrm{M}$ (López-Abbate et al. 2015), which is known to reduce chlorophyll content, cell abundance and productivity of estuarine phytoplankton (Livingston et al. 2002, Yoshiyama and Sharp 2006). Algal blooms resulting from cultural eutrophication are in fact associated with much lower $\mathrm{NH}_{4}{ }^{+}$concentration. For instance, in the San Francisco Estuary and in the Indian River Lagoon at Florida east coast, US, algal blooms were trigged at $\mathrm{NH}_{4}{ }^{+}$concentrations lower than $25 \mu \mathrm{M}$ (Dugdale et al. 2012, Lapointe et al. 2015). Heterotrophic bacteria also showed significantly lower biomass under severe eutrophication. Among Chicago metropolitan rivers, benthic bacteria evidenced vulnerability to wastewater effluents along with a loss of diversity (Drury et al. 2013). Authors hypothesized a mediating effect of toxic compounds such as antimicrobials contained in the effluents.

The vulnerability of microzooplankton to severe eutrophication during our summer experiments, was also verified by field observations, which revealed that eutrophication reduces microzooplankton biomass at the interannual time-scale (López-Abbate et al. 2015). Moreover, cultural eutrophication in the Bahía Blanca Estuary has been shown to reduce mesozooplankton biomass during summer (Dutto et al. 2012) and the fertility of the copepod Eurytemora americana (Berasategui et al. 2018). The negative effect on planktonic grazers was attributed to the combination of several factors, such as hypoxia (Dutto et al. 2012) and 
toxicity of $\mathrm{NH}_{4}{ }^{+}$and heavy metals (López-Abbate et al. 2015, Fernández Severini et al. 2017, Berasategui et al. 2018).

Given that the wastewater effluents impacted negatively on every microbial component, we hypothesize that the mediating factors were the toxic effect of $\mathrm{NH}_{4}{ }^{+}$and bottom-up regulation. In turn, an inefficient use of nutrients by primary producers, likely impacts on the overall carbon transfer across the entire food web (Schmoker et al. 2016). These results suggest that environmental quality degradation associated with the dumping of urban effluents can undermine the compensatory capacity of microbial communities and yield unexpected biological responses such as the drop of bacterial biomass.

\section{Eutrophication effect on carbon transfer among the microbial food web}

Excess nutrients under severe eutrophication sustained a higher growth rate of primary producers and heterotrophic bacteria, and reduced the biomass of all microbial components and the grazing of HNF and microzooplankton (Figure 8). This resulted in an inefficient trophic transfer of autotrophic and bacterial carbon. In eutrophic ecosystems, grazing by HNF is one of the most important pathways of bacterial biomass during summer (Tsai et al. 2013), while HNF biomass is efficiently relocated by top-down control (Wieltschnig et al. 2001). Our results evidenced that under the low influence of wastewater effluents, HNF grazed 154 $\%$ of daily bacterial production, while microzooplankton grazed $157 \%$ of total nanoplankton daily production. However, under the direct influence of wastewater effluents, the percentage of bacterial biomass grazed by HNF dropped to $33.7 \%$. It is worth noting that water turbidity above 50 NTU, as recorded in BM, reduces the abundance of ciliates (López-Abbate et al. 2019), which implies that significant differences on suspended particle concentration among sites may biased the calculation of rates. Low top-down control of HNF upon bacteria, 
however, was also documented under the effect of cultural eutrophication in the Kaštela Bay, Croatia (Šolić et al. 2010), and in many eutrophic lakes (Wieltschnig et al. 2001, Zingel et al. 2007, Fermani et al. 2014). The weak coupling between HNF and bacteria results in most cases from the strong top-down control of ciliates on HNF. Here, in contrast, we found a weak top-down control on HNF, therefore the question remains on whether the low grazing impact of HNF resulted from specific responses to nutrients and toxic effects or to changes in community composition. In addition, the handling of organisms during the preparation of size fractions, implies that many cells will suffer some damage, especially the pico (0.2-3 $\mu \mathrm{m})$ and nano-sized $(2-20 \mu \mathrm{m})$ fractions that were exposed to vacuum pressure. This procedure could lead to lower estimates of plankton growth and grazing and is not the preferable method for obtaining accurate rate estimates (Landry et al. 1984).

Severe eutrophication also reduced the grazing impact of microzooplankton on HNF as a result of an active prey switching toward the most abundant items (diatoms). Selective feeding of microzooplankton toward diatoms is probably linked with the stimulation of diatoms growth driven by nutrient enrichment. In fact, prey growth rate is a primary factor that activates the grazing of microzooplankton even in productive areas (Sanderson et al. 2012, López-Abbate et al. 2016). Significantly higher water turbidity in BM may be an additional factor explaining contrasting trophic pathways in both sites. In fact, the prey size spectrum of ciliates is within the size range of suspended sediments in the Bahía Blanca Estuary (Guinder et al. 2015), and a high concentration of inedible suspensoids likely interfered with grazers selectivity, especially in BM. Similar prey switching, from HNF to micro-sized phytoplankton, however, was reported in the Kaštela Bay under intense eutrophication (Šolić et al. 2010). The trophic decoupling between microzooplankton and HNF under severe eutrophication, constituted a dead-end of bacterial biomass and might 
produce a positive feedback with continuous eutrophication by exacerbating the accumulation of organic matter. Former investigations on fatty acid revealed that mesozooplankton in the Bahía Blanca Estuary also circumvent active feeding on HNF under severe eutrophication during summer, thus minimizing the carbon transfer from bacteria toward higher trophic levels (Dutto et al. 2014). The re-wiring of the microbial network driven by modifications in nutrient concentration, evidences that simply quantifying grazing rates may not fully disclose the mechanisms and feedbacks coupled to human-driven eutrophication. Since this study covers only the warm season, it remains unknown to what extent the observed trophic interactions change seasonally, although we may expect marked changes given the strong thermal dependence of microbial grazers (Domaizon et al. 2003, Rose and Caron 2007). Our results revealed that low trophic efficiency under severe eutrophication may aggravate the accumulation of organic matter thus accelerating habitat deterioration.

\section{Acknowledgment}

We thank Walter Melo for providing the study map and Martín Amodeo for his support in figure's drawing. This study was supported by the National Agency for Promotion of Science and Technology (FONCYT-PICT 1713), the National Scientific and Technical Research Council (CONICET) and by the Instituto Argentino de Oceanografía (CONICET-UNS). 


\section{Figure and tables captions}

Table 1 Mean value \pm 1 standard deviation (SD) and the number of replicates (n) of environmental variables in both sites. p-Values in bold $(<0.05)$ indicate significant differences between sites (One-way ANOVA).

\begin{tabular}{|l|c|c|c|c|}
\hline & BM & CV & $n$ & $p$ \\
\hline SST $\left({ }^{\circ} \mathrm{C}\right)$ & $22.20 \pm 0.70$ & $23.35 \pm 0.35$ & 3 & 0.176 \\
\hline Salinity & $40.33 \pm 0.09$ & $38.80 \pm 1.13$ & 3 & 0.196 \\
\hline Dissolved $\mathrm{O}_{2}\left(\mathrm{mg} \mathrm{l}^{-1}\right)$ & $6.32 \pm 0.16$ & $5.47 \pm 0.47$ & 3 & 0.139 \\
\hline$\% \mathrm{O}_{2}$ saturation & $88.00 \pm 0.28$ & $77.70 \pm 7.07$ & 3 & 0.176 \\
\hline $\mathrm{pH}$ & $8.25 \pm 0.035$ & $8.16 \pm 0.03$ & 3 & 0.126 \\
\hline $\mathrm{Turbidity}(\mathrm{NTU})$ & $160.50 \pm 30.41$ & $54.00 \pm 7.07$ & 3 & $\mathbf{0 . 0 4 0}$ \\
\hline $\mathrm{NH}_{4}{ }^{+}(\mu \mathrm{M})$ & $23.53 \pm 10.66$ & $161.83 \pm 56.07$ & 3 & $\mathbf{0 . 0 4 3}$ \\
\hline $\mathrm{NO}_{3}^{-}(\mu \mathrm{M})$ & $3.37 \pm 1.18$ & $9.69 \pm 0.07$ & 3 & $\mathbf{0 . 0 0 1}$ \\
\hline $\mathrm{NO}_{2}^{-}(\mu \mathrm{M})$ & $1.66 \pm 0.33$ & $2.47 \pm 0.03$ & 3 & $\mathbf{0 . 0 1 3}$ \\
\hline $\mathrm{PO}_{3}^{-4}(\mu \mathrm{M})$ & $0.92 \pm 0.49$ & $3.53 \pm 0.42$ & 3 & $\mathbf{0 . 0 0 2}$ \\
\hline $\mathrm{Si}^{-}(\mu \mathrm{M})$ & $45.79 \pm 12.39$ & $67.17 \pm 0.32$ & 3 & $\mathbf{0 . 0 4 0}$ \\
\hline
\end{tabular}

Table 2 One-way ANOVA of the effects of site (BM vs. CV) on the growth $(\mu)$, production $(\mathrm{P})$, grazing $(\mathrm{m})$ and filtration rates $(\mathrm{F})$. Mean comparison of triplicate rate estimates was performed for each corresponding prey and grazer item. p-Values in bold $(<0.05)$ indicate significant differences between sites (One-way ANOVA).

\begin{tabular}{|l|c|c|c|c|c|c|c|c|}
\hline & \multicolumn{2}{|c|}{$\boldsymbol{\mu}$} & \multicolumn{2}{c}{$\mathbf{P}$} & \multicolumn{2}{c|}{$\mathbf{m}$} & \multicolumn{2}{c|}{$\mathbf{F}$} \\
\hline & $\mathrm{p}$ & $\mathrm{R}^{2}$ & $\mathrm{p}$ & $\mathrm{R}^{2}$ & $\mathrm{p}$ & $\mathrm{R}^{2}$ & $\mathrm{p}$ & $\mathrm{R}^{2}$ \\
\hline Bacteria & 0.165 & 0.273 & 0.248 & 0.142 & $\mathbf{0 . 0 0 1}$ & 0.945 & 0.297 & 0.081 \\
\hline Diatoms & $\mathbf{0 . 0 0 8}$ & 0.823 & $\mathbf{0 . 0 4 6}$ & 0.588 & 0.120 & 0.366 & 0.243 & 0.148 \\
\hline PNF & 0.114 & 0.380 & 0.611 & 0.000 & 0.665 & 0.000 & 0.288 & 0.091 \\
\hline HNF & 0.182 & 0.243 & $\mathbf{0 . 0 4 7}$ & 0.583 & $\mathbf{0 . 0 0 3}$ & 0.897 & $\mathbf{0 . 0 2 0}$ & 0.723 \\
\hline Microzooplankton & 0.109 & 0.392 & 0.243 & 0.149 & - & - & - & - \\
\hline
\end{tabular}




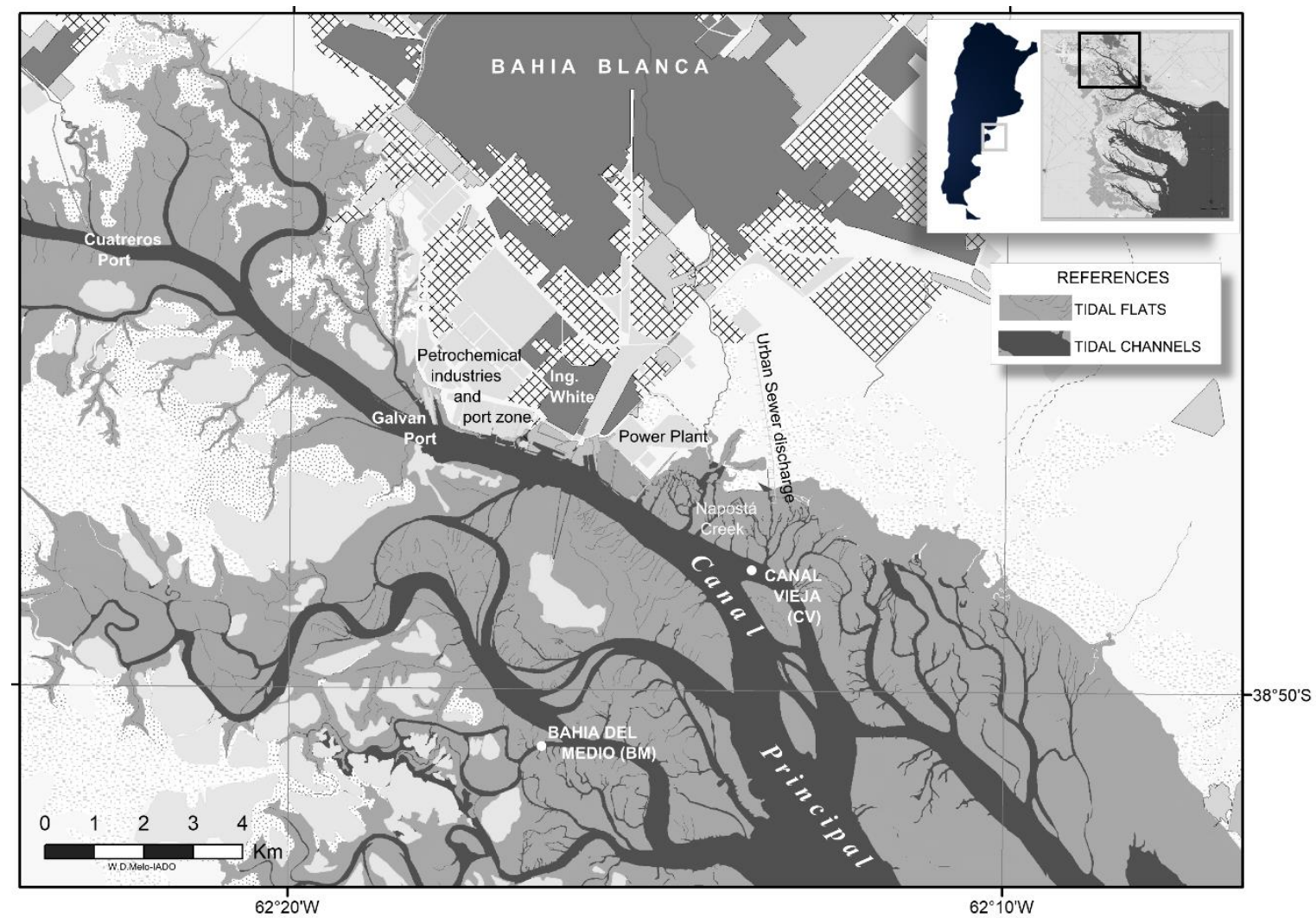

Fig. 1. Sampling area showing the location of two sampling sites exposed to moderate (Bahía del Medio, BM) and high anthropogenic eutrophication (Canal Vieja, CV). 


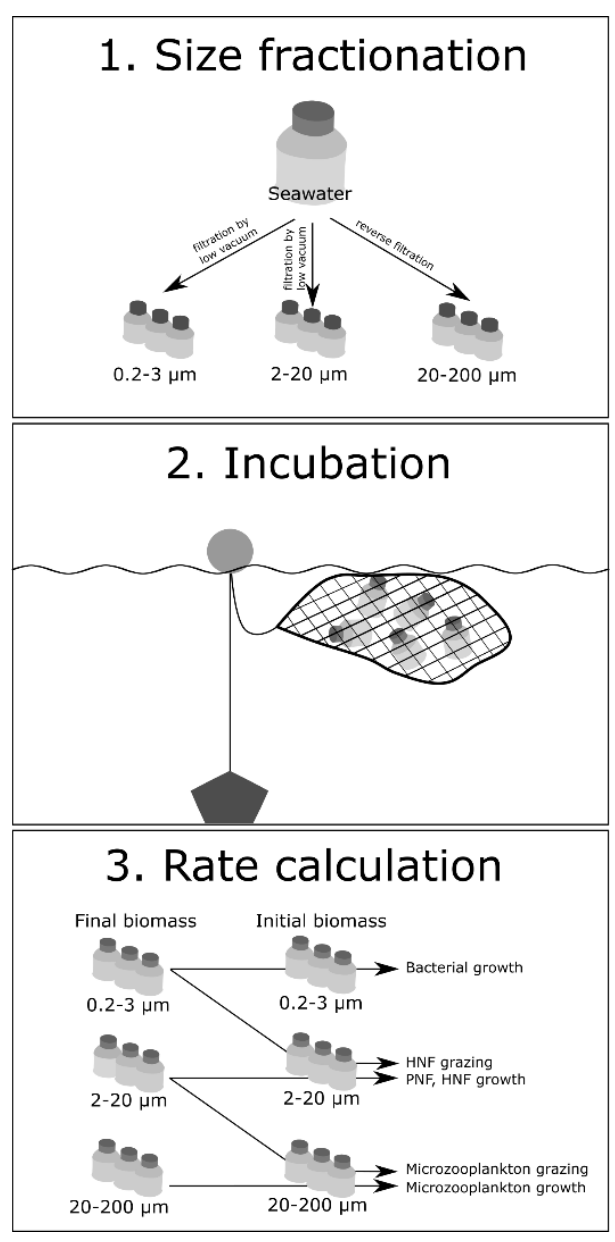

Fig. 2. Scheme showing the experimental protocol used in the size-fractionation method. The first step (upper panel) involves the elimination of size-specific grazers by filtering whole seawater to obtain the following size-fractions: $0.2-3 \mu \mathrm{m}$ (bacteria and cyanobacteria), 2-20 $\mu \mathrm{m}$ (diatoms and other phytoplankton, phototrophic $[\mathrm{PNF}]$ and heterotrophic nanoflagellates [HNF]) and 20-135 $\mu \mathrm{m}$ (microphytoplankton and microzooplankton). Triplicate sets of sizefractions were immediately taken for incubation to the sampling site to maintain in situ temperature and photoperiod. Bottles were placed on net bags near the surface and fixed to the bottom by an anchor (medium panel). After $24 \mathrm{~h}$ incubation, growth and grazing rates were estimated by confronting the initial and final biomass of organisms in the presence and absence of grazers (lower panel). 


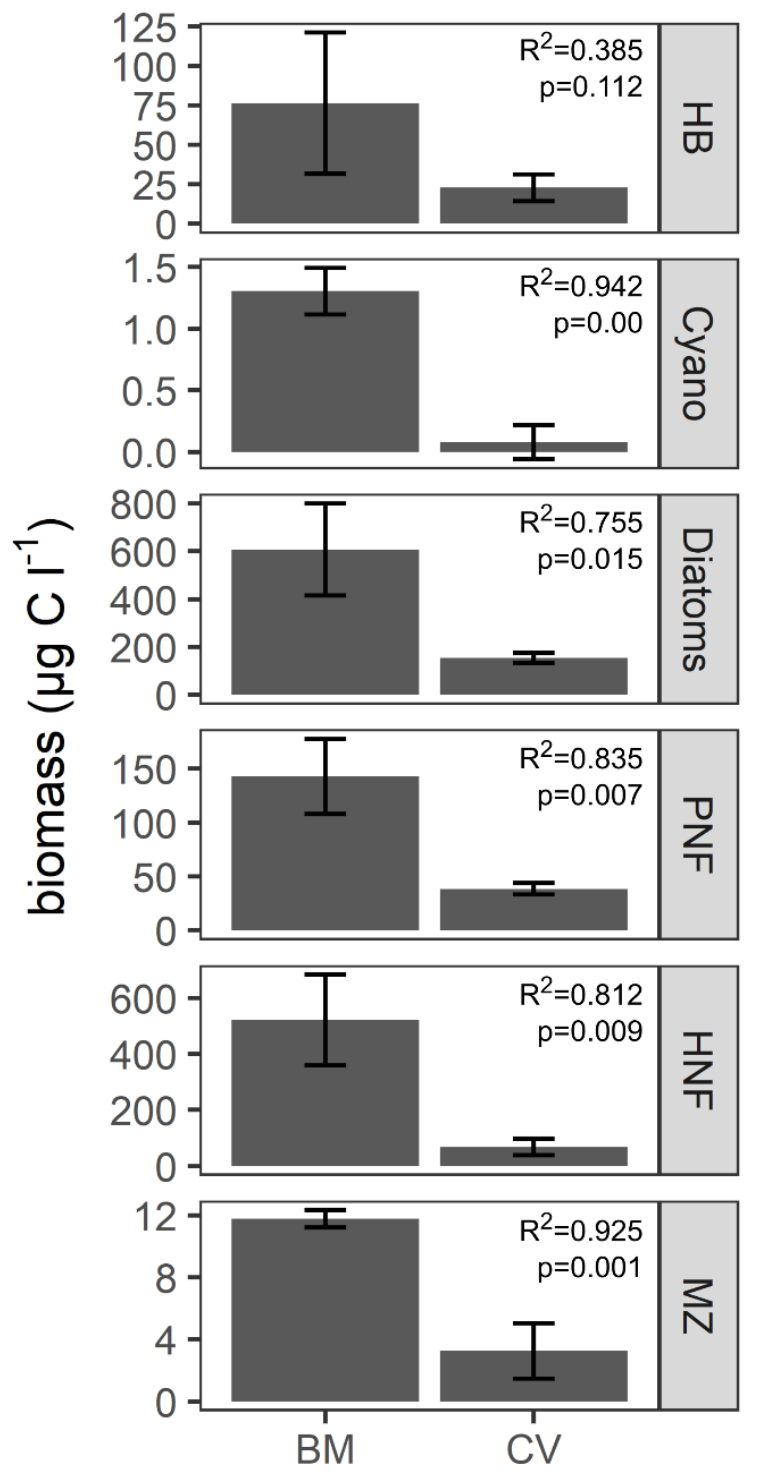

Fig. 3. Mean value $\pm 1 \mathrm{SD}$ of the biomass $\left(\mu \mathrm{g} \mathrm{C}^{-1}\right)$ of heterotrophic bacteria (HB), cyanobacteria (cyano), diatoms, phototrophic nanoflagellates (PNF), heterotrophic nanoflagellates (HNF) and microzooplankton (MZ) under moderate (BM) and high (CV) exposure to cultural eutrophication. Mean values were computed based on triplicate samples taken at the beginning of the experiment. 


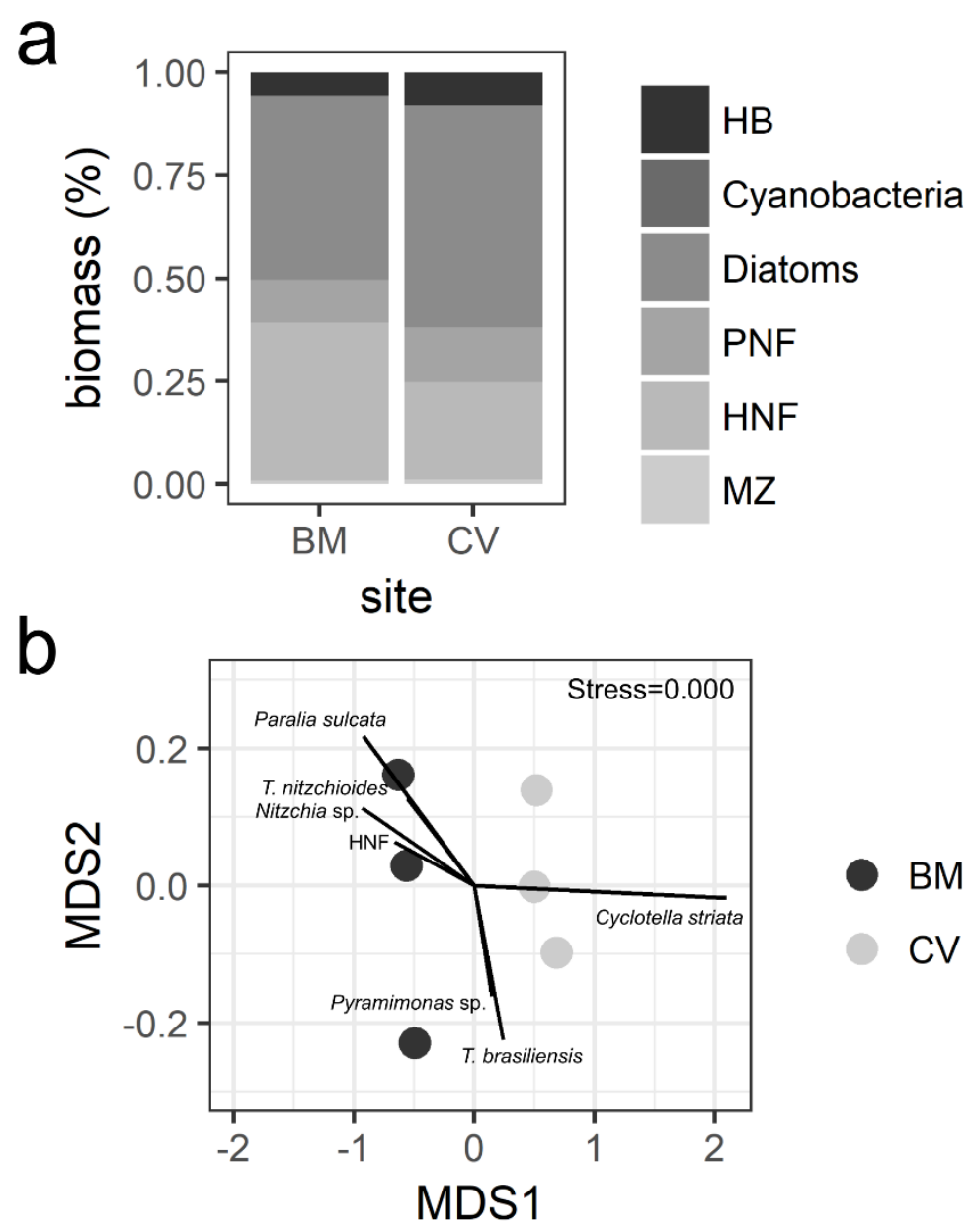

Fig. 4A. Relative biomass contribution $(\%)$ of the microbial community under moderate $(\mathrm{BM})$ and high (CV) exposure to cultural eutrophication. PNF: phototrophic nanoflagellates, HNF: heterotrophic nanoflagellates, MZ: microzooplankton. B. Multi-dimensional scaling analysis of microbial community with site (BM and $\mathrm{CV})$ as discriminating factor. Stress values of the analysis are shown in the left upper corner of the plot. Species that showed significant correlation with the ordination configuration $(\mathrm{p}<0.05)$ are also shown. 

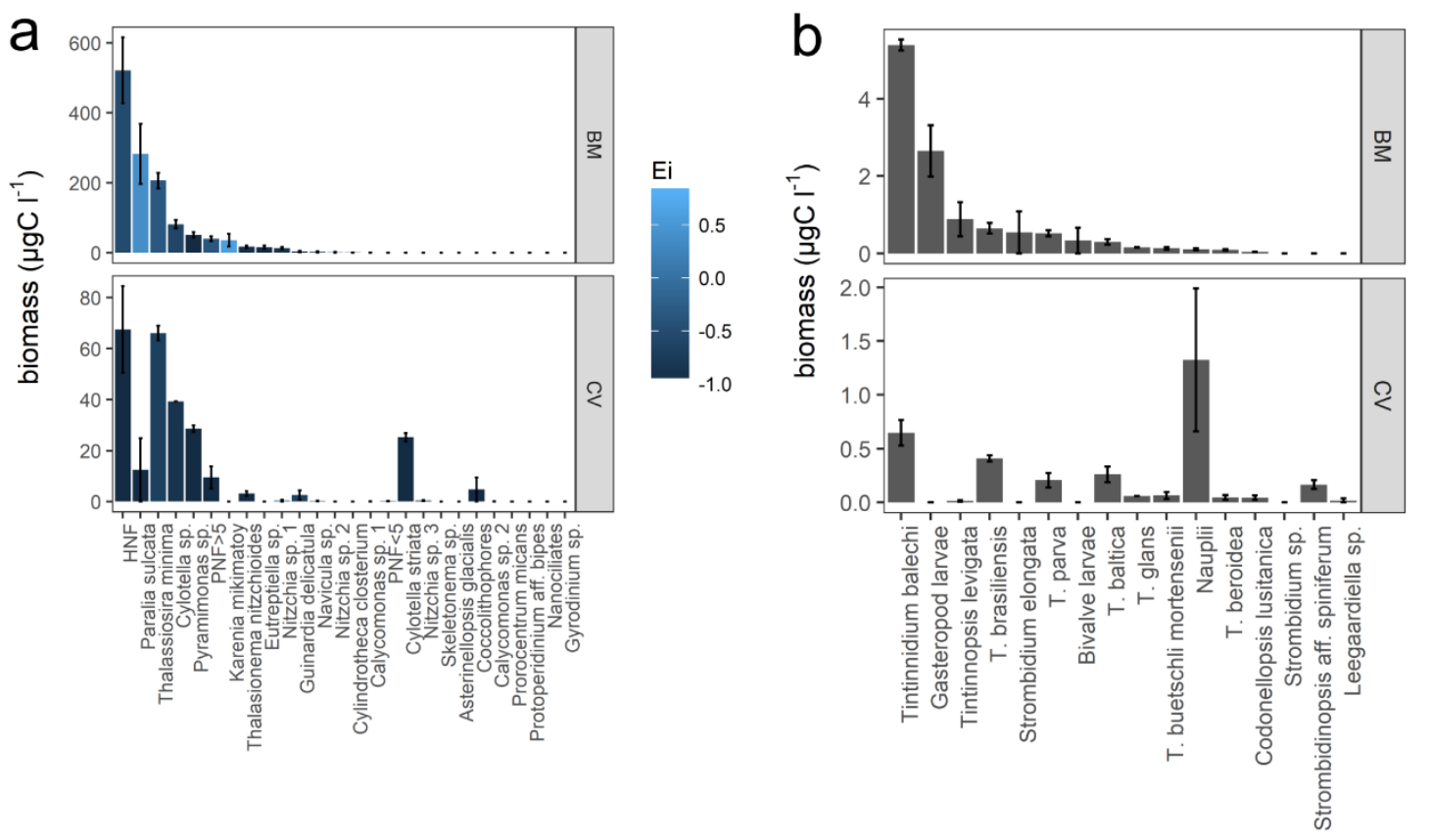

Fig. 5A. Mean value $\pm 1 \mathrm{SD}$ of the biomass of nanoplankton at the beginning of the experiment under moderate $(\mathrm{BM})$ and high $(\mathrm{CV})$ exposure to cultural eutrophication. Colour scale denotes the trophic selectivity index (Ei) of microzooplankton over each item. B. Mean value $\pm 1 \mathrm{SD}$ of the biomass of microzooplankton at the beginning of the experiment under moderate (BM) and high (CV) exposure to cultural eutrophication. 


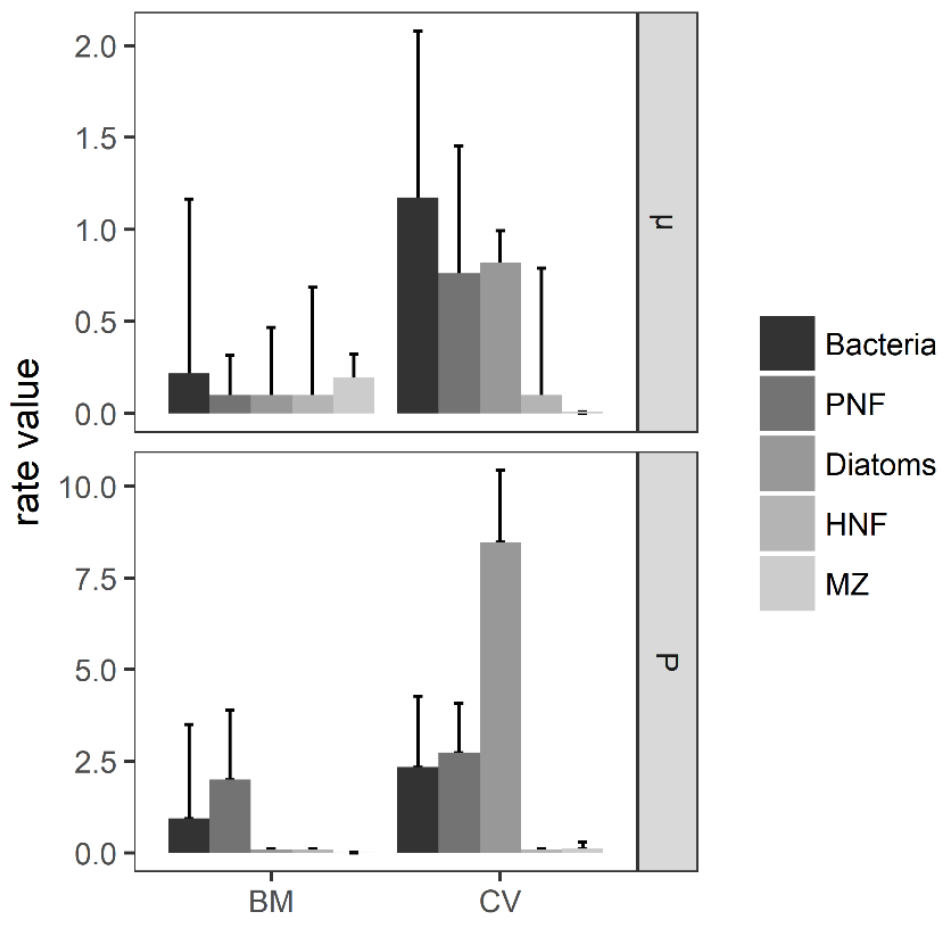

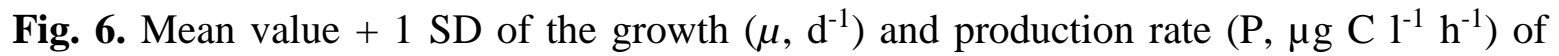
bacteria, phototrophic nanoflagellates (PNF), diatoms, heterotrophic nanoflagellates (HNF) and microzooplankton $(\mathrm{MZ})$ under moderate $(\mathrm{BM})$ and high $(\mathrm{CV})$ exposure to cultural eutrophication. 

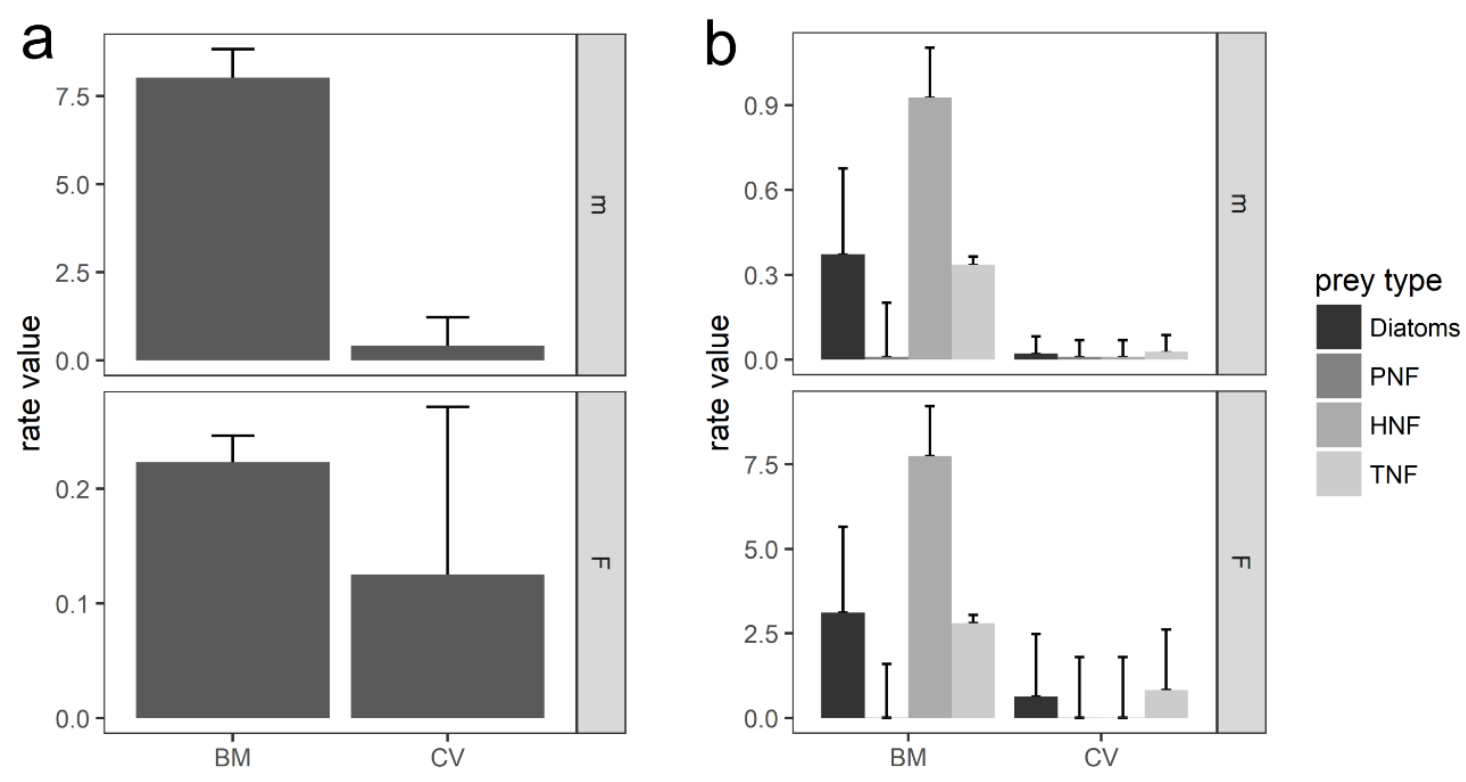

Fig. 7. Mean value $+1 \mathrm{SD}$ of the grazing $\left(m, \mathrm{~d}^{-1}\right)$ and filtration rates $\left(\mathrm{F}, \mu \mathrm{g}\right.$ grazer $\left.^{-1} \mathrm{~h}^{-1}\right)$ of heterotrophic nanoflagellates over bacteria (A) and microzooplankton over specific prey items (B) under moderate $(\mathrm{BM})$ and high $(\mathrm{CV})$ exposure to cultural eutrophication. PNF: phototrophic nanoflagellates, HNF: heterotrophic nanoflagellates, MZ: microzooplankton, TNF: total nanoflagellates. 


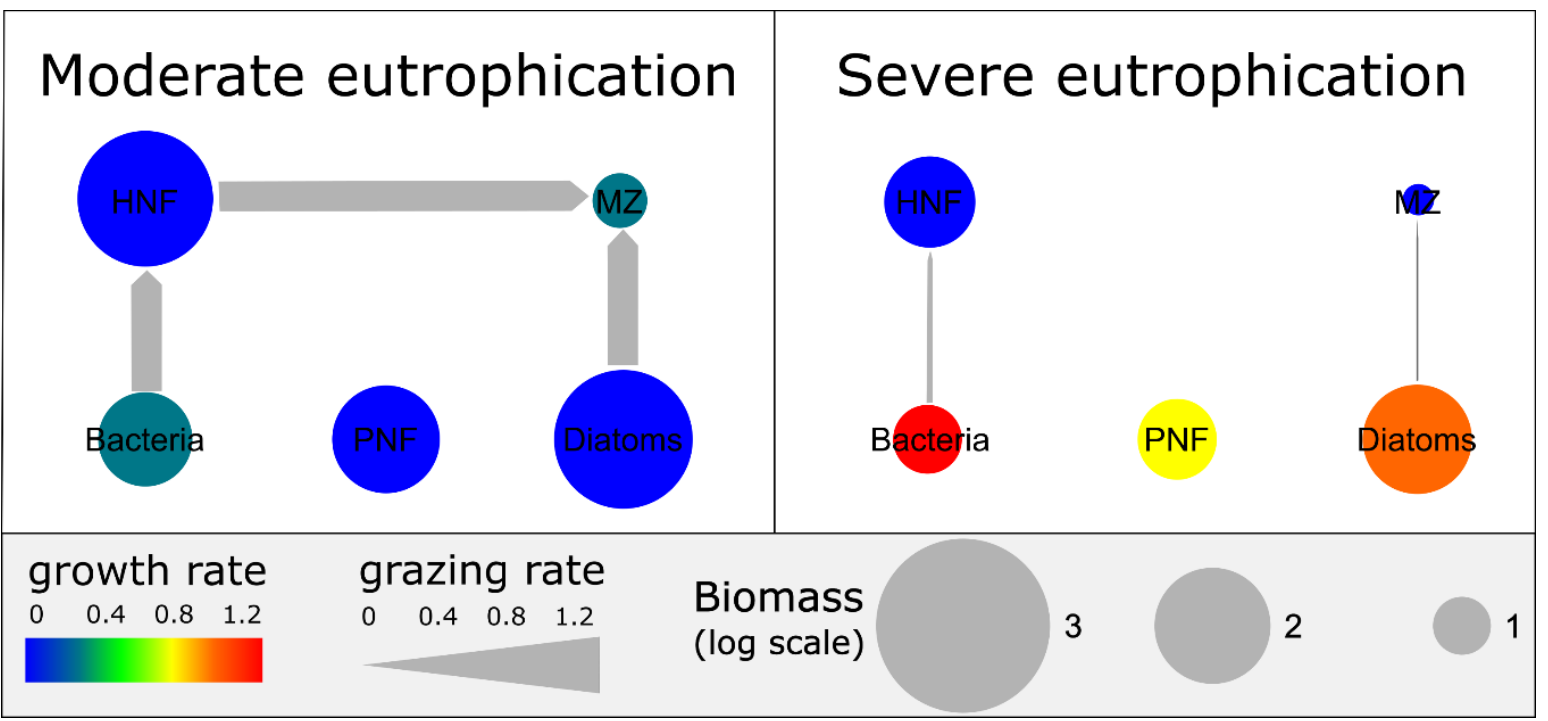

Fig. 8. Trophic transfer pathways under moderate (A) and high (B) cultural eutrophication. Colour scale of circles denotes the specific growth rate $\left(\mu, \mathrm{d}^{-1}\right)$, while grazing impact on daily prey productivity ( $m: \mu$, dimensionless) is indicated by the arrow width. The area of the circles represents carbon biomass of each component in logarithmic scale. PNF: phototrophic nanoflagellates, HNF: heterotrophic nanoflagellates, MZ: microzooplankton.

\section{References}

Baldini, M., M. Cubitto, M. Chiarello, and C. Cabezalí. 1999. Water quality for aquaculture development in Bahía Blanca estuary, Argentina. Bacteriological studies. Revista Argentina de microbiologia 31:19-24.

Barría de Cao, M. S., M. C. Piccolo, and G. M. Perillo. 2011. Biomasss and microzooplankton seasonal assemblages in the Bahía Blanca Estuary, Argentinean Coast. Journal of the Marine Biological Association of the United Kingdom 91:953-959.

Berasategui, A. A., F. Biancalana, A. Fricke, M. D. Fernandez-Severini, R. Uibrig, M. S. Dutto, J. Marcovecchio, D. Calliari, and M. S. Hoffmeyer. 2018. The impact of sewage effluents on the fecundity and survival of Eurytemora americana in a eutrophic estuary of Argentina. Estuarine, Coastal and Shelf Science 211:208-216.

Bong, C. W. and C. W. Lee. 2011. The contribution of heterotrophic nanoflagellate grazing towards bacterial mortality in tropical waters: comparing estuaries and coastal ecosystems. Marine and Freshwater Research 62:414-420.

Breton, E., V. Rousseau, J.-Y. Parent, J. Ozer, and C. Lancelot. 2006. Hydroclimatic modulation of diatom/Phaeocystis blooms in nutrient-enriched Belgian coastal waters (North Sea). Limnology and Oceanography 51:1401-1409. 
Calbet, A. and M. R. Landry. 2004. Phytoplankton growth, microzooplankton grazing, and carbon cycling in marine systems. Limnology and Oceanography 49:51-57.

Calbet, A., A. F. Sazhin, J. C. Nejstgaard, S. A. Berger, Z. S. Tait, L. Olmos, D. Sousoni, S. Isari, R. A. Martínez, J.-M. Bouquet, E. M. Thompson, U. Båmstedt, and H. H. Jakobsen. 2014. Future climate scenarios for a coastal productive planktonic food web resulting in microplankton phenology changes and decreased trophic transfer efficiency. PLoS One 9:e94388.

Clarke, K. and R. Warwick. 1994. Change in marine communities: an approach to statistical analysis and interpretation. Plymouth Marine Laboratory, Plymouth, UK.

Cox, T., T. Maris, K. Soetaert, D. Conley, S. Van Damme, P. Meire, J. J. Middelburg, M. Vos, and E. Struyf. 2009. A macro-tidal freshwater ecosystem recovering from hypereutrophication: the Schelde case study. Biogeosciences 6:2935-2948.

D'Alelio, D., S. Libralato, T. Wyatt, and M. Ribera d'Alcalà. 2016. Ecological-network models link diversity, structure and function in the plankton food-web. Sci Rep 6:21806.

Domaizon, I., S. Viboud, and D. Fontvieille. 2003. Taxon-specific and seasonal variations in flagellates grazing on heterotrophic bacteria in the oligotrophic Lake Annecy - importance of mixotrophy. FEMS Microbiology Ecology 46:317-329.

Domingues, R. B., A. B. Barbosa, U. Sommer, and H. M. Galvão. 2011. Ammonium, nitrate and phytoplankton interactions in a freshwater tidal estuarine zone: potential effects of cultural eutrophication. Aquatic Sciences 73:331-343.

Drury, B., E. Rosi-Marshall, and J. J. Kelly. 2013. Wastewater treatment effluent reduces the abundance and diversity of benthic bacterial communities in urban and suburban rivers. Applied and Environmental Microbiology 79:1897-1905.

Dugdale, R., F. Wilkerson, A. E. Parker, A. Marchi, and K. Taberski. 2012. River flow and ammonium discharge determine spring phytoplankton blooms in an urbanized estuary. Estuarine, Coastal and Shelf Science 115:187-199.

Dugdale, R. C., F. P. Wilkerson, V. E. Hogue, and A. Marchi. 2007. The role of ammonium and nitrate in spring bloom development in San Francisco Bay. Estuarine, Coastal and Shelf Science 73:17-29.

Dutto, M. S., G. A. Kopprio, M. S. Hoffmeyer, T. S. Alonso, M. Graeve, and G. Kattner. 2014. Planktonic trophic interactions in a human-impacted estuary of Argentina: a fatty acid marker approach. Journal of Plankton Research 36:776-787.

Dutto, M. S., M. C. López-Abbate, F. Biancalana, A. A. Berasategui, and M. S. Hoffmeyer. 2012. The impact of sewage on environmental quality and the mesozooplankton community in a highly eutrophic estuary in Argentina. ICES Journal of Marine Science 69:399-409.

Fermani, P., A. Torremorell, L. Lagomarsino, R. Escaray, F. Unrein, and G. Pérez. 2014. Microbial abundance patterns along a transparency gradient suggest a weak coupling between heterotrophic bacteria and flagellates in eutrophic shallow Pampean lakes. Hydrobiologia 752:103-123.

Fernández Severini, M. D., D. M. Villagran, F. Biancalana, A. A. Berasategui, C. V. Spetter, M. N. Tartara, M. C. Menéndez, V. A. Guinder, and J. Marcovecchio. 2017. Heavy metal concentrations found in seston and microplankton from an impacted temperate shallow estuary along the Southwestern Atlantic Ocean. Journal of Coastal Research 33:1196-1209.

Frost, B. 1972. Effects of size and concentration of food particles on the feeding behavior of the marine planktonic copepod Calanus pacificus. Limnology and Oceanography 17:805-815.

Ger, K. A., L.-A. Hansson, and M. Lürling. 2014. Understanding cyanobacteria-zooplankton interactions in a more eutrophic world. Freshw Biol 59:1783-1798. 
Gifford, D. 1993. Consumption of protozoa by copepods feeding on natural microplankton assemblages. Handbook of methods in aquatic microbial ecology. Lewis Publishers, Boca Raton:723-729.

Glavovic, B. C., K. Limburg, K. K. Liu, K. C. Emeis, H. Thomas, H. Kremer, B. Avril, J. Zhang, M. R. Mulholland, M. Glaser, and D. P. Swaney. 2015. Living on the margin in the anthropocene: engagement arenas for sustainability research and action at the ocean-land interface. Current Opinion in Environmental Sustainability 14:232-238.

Glibert, P. M., F. P. Wilkerson, R. C. Dugdale, A. E. Parker, J. Alexander, S. Blaser, and S. Murasko. 2014. Phytoplankton communities from San Francisco Bay Delta respond differently to oxidized and reduced nitrogen substrates-even under conditions that would otherwise suggest nitrogen sufficiency. Frontiers in Marine Science 1:1-16.

Guinder, V. A., M. C. López-Abbate, A. A. Berasategui, V. L. Negrin, G. Zapperi, P. D. Pratolongo, M. D. Fernández Severini, and C. A. Popovich. 2015. Influence of the winter phytoplankton bloom on the settled material in a temperate shallow estuary. Oceanologia 57:50-60.

Guinder, V. A., J. C. Molinero, C. A. Popovich, J. E. Marcovecchio, and U. Sommer. 2013. Dominance of the planktonic diatom Thalassiosira minima in recent summers in the Bahia Blanca Estuary, Argentina. Journal of Plankton Research 34:995-1000.

Hasle, G. R. 1978. The inverted microscope method. Pages 88-96 in A. Sournia, editor. Phytoplankton Manual. UNESCO, Paris.

Hillebrand, H., C. D. Dürselen, D. Kirschtel, U. Pollingher, and T. Zohary. 1999. Biovolume calculation for pelagic and benthic microalgae. Journal of phycology 35:403-424.

Hoffmeyer, M. S. and M. S. Barría de Cao. 2007. Zooplankton assemblages from a tidal channel in the Bahía Blanca Estuary, Argentina. Brazilian Journal of Oceanography 55:97-107.

Landry, M., L. Haas, and V. Fagerness. 1984. Dynamics of microbial plankton communities: experiments in Kaneohe Bay, Hawaii. Marine Ecology Progress Series 16:127.

Lapointe, B. E., L. W. Herren, D. D. Debortoli, and M. A. Vogel. 2015. Evidence of sewage-driven eutrophication and harmful algal blooms in Florida's Indian River Lagoon. Harmful Algae 43:82-102.

Livingston, R. J., A. K. Prasad, X. Niu, and S. E. McGlynn. 2002. Effects of ammonia in pulp mill effluents on estuarine phytoplankton assemblages: field descriptive and experimental results. Aquatic Botany 74:343-367.

López-Abbate, M. C., M. S. Barría de Cao, R. E. Pettigrosso, V. A. Guinder, M. S. Dutto, A. A. Berasategui, C. J. Chazarreta, and M. S. Hoffmeyer. 2016. Seasonal changes in microzooplankton feeding behavior under varying eutrophication level in the Bahía Blanca estuary (SW Atlantic Ocean). Journal of Experimental Marine Biology and Ecology 481:2533.

López-Abbate, M. C., J. C. Molinero, V. A. Guinder, M. S. Dutto, M. S. Barria de Cao, L. A. Ruiz Etcheverry, R. E. Pettigrosso, M. C. Carcedo, and M. S. Hoffmeyer. 2015. Microplankton dynamics under heavy anthropogenic pressure. The case of the Bahia Blanca Estuary, southwestern Atlantic Ocean. Mar Pollut Bull 95:305-314.

López-Abbate, M. C., J. C. Molinero, G. M. Perillo, M. S. Barría de Cao, R. E. Pettigrosso, V. A. Guinder, R. Uibrig, A. A. Berasategui, A. Vitale, J. E. Marcovecchio, and M. S. Hoffmeyer. 2019. Longterm changes on estuarine ciliates linked with modifications on wind patterns and water turbidity. Marine Environmental Reseacr in press.

Malzahn, A. M., F. Hantzsche, K. L. Schoo, M. Boersma, and N. Aberle. 2010. Differential effects of nutrient-limited primary production on primary, secondary or tertiary consumers. Oecologia 162:35-48. 
McCarthy, M. J., P. J. Lavrentyev, L. Yang, L. Zhang, Y. Chen, B. Qin, and W. S. Gardner. 2007. Nitrogen dynamics and microbial food web structure during a summer cyanobacterial bloom in a subtropical, shallow, well-mixed, eutrophic lake (Lake Taihu, China). Hydrobiologia 581:195207.

Meunier, C. L., A. M. Malzahn, and M. Boersma. 2014. A new approach to homeostatic regulation: towards a unified view of physiological and ecological concepts. PLoS One 9:e107737.

Mills, M. M. and K. R. Arrigo. 2010. Magnitude of oceanic nitrogen fixation influenced by the nutrient uptake ratio of phytoplankton. Nature Geoscience 3:412.

Officer, C. and J. Ryther. 1980. The possible importance of silicon in marine eutrophication. Marine Ecology Progress Series:83-91.

Ortmann, A. C., R. C. Metzger, J. D. Liefer, and L. Novoveska. 2011. Grazing and viral lysis vary for different components of the microbial community across an estuarine gradient. Aquatic Microbial Ecology 65:143-157.

Özen, A., Ü. N. Tavşanoğlu, A. İ. Çakıroğlu, E. E. Levi, E. Jeppesen, and M. Beklioğlu. 2017. Patterns of microbial food webs in Mediterranean shallow lakes with contrasting nutrient levels and predation pressures. Hydrobiologia 806:13-27.

Paerl, H. W., N. S. Hall, B. L. Peierls, and K. L. Rossignol. 2014. Evolving paradigms and challenges in estuarine and coastal eutrophication dynamics in a culturally and climatically stressed world. Estuaries and Coasts 37:243-258.

Panizzo, V. N., S. Roberts, G. E. A. Swann, S. McGowan, A. W. Mackay, E. Vologina, V. Pashley, and M. S. A. Horstwood. 2018. Spatial differences in dissolved silicon utilization in Lake Baikal, Siberia: Examining the impact of high diatom biomass events and eutrophication. Limnology and Oceanography 63:1562-1578.

Parker, A. E., R. C. Dugdale, and F. P. Wilkerson. 2012. Elevated ammonium concentrations from wastewater discharge depress primary productivity in the Sacramento River and the Northern San Francisco Estuary. Mar Pollut Bull 64:574-586.

Paulsen, M. L., H. Doré, L. Garczarek, L. Seuthe, O. Müller, R.-A. Sandaa, G. Bratbak, and A. Larsen. 2016. Synechococcus in the Atlantic Gateway to the Arctic Ocean. Frontiers in Marine Science 3.

Porter, K. G. and Y. S. Feig. 1980. The use of DAPI for identifying and counting aquatic microflora. Limnology and Oceanography 25:943-948.

Rose, J. M. and D. A. Caron. 2007. Does low temperature constrain the growth rates of heterotrophic protists? Evidence and implications for algal blooms in cold waters. Limnology and Oceanography 52:886-895.

Sanderson, B. G., A. M. Redden, and K. Evans. 2012. Grazing constants are not constant: Microzooplankton grazing is a function of phytoplankton production in an Australian lagoon. Estuaries and Coasts 35:1270-1284.

Sato, M., T. Yoshikawa, S. Takeda, and K. Furuya. 2007. Application of the size-fractionation method to simultaneous estimation of clearance rates by heterotrophic flagellates and ciliates of pico- and nanophytoplankton. Journal of Experimental Marine Biology and Ecology 349:334343.

Schmoker, C., S. Hernández-León, and A. Calbet. 2013. Microzooplankton grazing in the oceans: impacts, data variability, knowledge gaps and future directions. Journal of Plankton Research 35:691-706.

Schmoker, C., F. Russo, G. Drillet, A. Trottet, M. S. Mahjoub, S. H. Hsiao, O. Larsen, K. Tun, and A. Calbet. 2016. Effects of eutrophication on the planktonic food web dynamics of marine coastal ecosystems: The case study of two tropical inlets. Mar Environ Res 119:176-188. 
Simon, M. and F. Azam. 1989. Protein content and protein synthesis rates of planktonic marine bacteria. Marine Ecology Progress Series:201-213.

Šolić, M., N. Krstulović, G. Kušpilić, Ž. Ninčević Gladan, N. Bojanić, S. Šestanović, D. Šantić, and M. Ordulj. 2010. Changes in microbial food web structure in response to changed environmental trophic status: A case study of the Vranjic Basin (Adriatic Sea). Mar Environ Res 70:239-249.

Spetter, C. V., C. A. Popovich, A. Arias, R. O. Asteasuain, R. H. Freije, and J. E. Marcovecchio. 2015. Role of nutrients in phytoplankton development during a winter diatom bloom in a eutrophic South American estuary (Bahía Blanca, Argentina). Journal of Coastal Research 31:76-87.

Suikkanen, S., S. Pulina, J. Engström-Öst, M. Lehtiniemi, S. Lehtinen, and A. Brutemark. 2013. Climate change and eutrophication induced shifts in northern summer plankton communities. PLoS One 8:e66475.

Trautwein, K., C. Feenders, R. Hulsch, H. S. Ruppersberg, A. Strijkstra, M. Kant, J. Vagts, D. Wünsch, B. Michalke, M. Maczka, S. Schulz, H. Hillebrand, B. Blasius, and R. Rabus. 2017. NonRedfield, nutrient synergy and flexible internal elemental stoichiometry in a marine bacterium. FEMS Microbiology Ecology 93:fix059-fix059.

Tsai, A.-Y., G.-C. Gong, R. W. Sanders, and J.-K. Huang. 2013. Contribution of viral lysis and nanoflagellate grazing to bacterial mortality in the inner and outer regions of the Changjiang River plume during summer. Journal of Plankton Research 35:1283-1293.

Vanderploeg, H. and D. Scavia. 1979. Two electivity indices for feeding with special reference to zooplankton grazing. Journal of the Fisheries Board of Canada 36:362-365.

Vargas, C. A., R. A. Martinez, H. E. González, and S. Silva. 2008. Contrasting trophic interactions of microbial and copepod communities in a fjord ecosystem, Chilean Patagonia. Aquatic Microbial Ecology 53:227-242.

Verity, P. G. and M. E. Sieracki. 1993. Use of color image analysis and epifluorescence microscopy to measure plankton biomass. Handbook of methods in aquatic microbial ecology. Lewis Publishers, Boca Raton:327-338.

Waiser, M. J., V. Tumber, and J. Holm. 2011. Effluent-dominated streams. Part 1: Presence and effects of excess nitrogen and phosphorus in Wascana Creek, Saskatchewan, Canada. Environmental Toxicology and Chemistry 30:496-507.

Wieltschnig, C., A. K. T. Kirschner, A. Steitz, and B. Velimirov. 2001. Weak coupling between heterotrophic nanoflagellates and bacteria in a eutrophic freshwater environment. Microb Ecol 42:159-167.

Yoshiyama, K. and J. H. Sharp. 2006. Phytoplankton response to nutrient enrichment in an urbanized estuary: Apparent inhibition of primary production by overeutrophication. Limnology and Oceanography 51:424-434.

Zingel, P., H. Agasild, T. Noges, and V. Kisand. 2007. Ciliates are the dominant grazers on pico-and nanoplankton in a shallow, naturally highly eutrophic lake. Microb Ecol 53:134-142. 